regarded as best calculated to advance the student's training in methods of research. The Council also offers research fellowships for candidates of similar qualifications who have already had some experience in the use of research methods. Each fellowship will be tenable for one year at the ordinary value of $£ 250$ per annum, and will be renewable in approved instances at the rate of $£ 300$ per annum for a second year. Further information can be obtained from the Secretary, Medical Research Council, 38 Old Queen Street, London, S.W.1.

\section{French Association of Microbiologists}

ON the initiative of Profs. Bordet, director of the Pasteur Institute of Belgium, Martin, director of the Pasteur Institute of Paris, and Lisbonne, of the Montpellier faculty of medicine, an association of French-speaking microbiologists was formed at a meeting held in October 1937. The first meeting of the new association will be held in October next on the occasion of the fiftieth year of the foundation of the Pasteur Institute of Paris, with Prof. Martin as president, and Drs. Lépine of the Pasteur Institute of Paris and Paul Bordet of the Pasteur Institute of Brussels as general secretaries. Further information can be obtained from Dr. Lépine, Institut Pasteur, 25 rue du Docteur Roux, Paris $15^{\mathrm{e}}$.

\section{Announcements}

CaPtaIn Eyston in his motor-car Thunderbolt broke the world's land speed record on Bonneville Salt Flats, Utah, on August 27. Over the measured mile, the car averaged 345.49 m.p.h. for both ways; the outward run being 347.49 m.p.h., and the return 343.51 m.p.h. The former record, established also by Captain Eyston in 1937, was 311.42 m.p.h. The Thunderbolt has two Rolls-Royce engines, each capable of developing up to 2,350 h.p.

Dr. T. H. SANDERSon-WELLS has endowed an annual lectureship at the Middlesex Hospital Medical School on the relations between rheumatism and dietetics.

Dr. WILhelm A. P. SchüFFner, director of the Department of Tropical Hygiene at the Royal Colonial Institute of Amsterdam, has been awarded the Gold Medal of Honour by the Hanseatic University of Hamburg.

THE College of Physicians of Philadelphia has awarded the Alvarenga Prize to Dr. Richard E. Shope, of the Rockefeller Institute for Medical Research, Princeton, N.J., for his recent researches on the etiology and epidemiology of influenza.

THe twenty-seventh meeting of the Italian Society for the Advancement of Science will be held at Bologna under the presidency of the rector of the University on September 4-11.

THE twenty-fifth French Congress of Hygiene will be held at the Pasteur Institute, Paris, on October
3-8, when the following subjects will be discussed : the plan of the sanitary equipment of France; diet and public health; insurance and public health. Further information can be obtained from the General Secretary, Dr. X. Leclainche, 18 rue de Tilsitt, Paris $17^{\mathrm{e}}$.

THE sixth Congress of Physical Re-education organized by the French Society of Specialists in Medical Physical Culture will be held on September 10-12 at the Institute of Physical Education of the University of Paris with Prof. Roussy, rector of the University, as president of honour. It will consist of three sections devoted respectively to science applied to physical education and medical gymnastics, the technique of re-education and social realization. Further information can be obtained from the president of the Society, M. Petat, 11 rue Racine, Montluçon, Allier, France.

THE tenth Congress of the Far Eastern Association of Tropical Medicine, which meets every three years, will be held at Hanoi, Tonkin, on November 24-30, when the following subjects will be discussed: deficiency diseases, water supply, cholera, malaria, plague, tuberculosis, venereal disease, surgery, diseases common to man and animals, parasitology, and materia medica of the Far East. The official languages will be English and French. Further information can be obtained from the Organizing Committee, 6 rue de la Convention, Hanoi.

THE fourth International Conference on Timber Utilization is to be held in Brussels on September 15-17. The subjects to be dealt with include tests on the strength of timber in relation to building regulations, timber and plywood for aeroplanes, shipbuilding, etc., and modern possibilities of the utilization of sawmill waste, and reports on the activities of the Department for Timber Utilization. Further information relating to the Conference can be obtained from the Secretary, Comité International du Bois, 50 rue Neuve, Brussels, Belgium.

Messrs. Adlard and Son, Ltd, have issued a useful diary for the academic year 1938-39, copies of which were presented to members of the British Association attending the recent meeting in Cambridge. It includes, against the appropriate dates, notes of the meetings of learned societies, and there is also a table showing the dates of the terms of the universities of the British Isles.

British Drug Houses, Lto., have issued a descriptive leaflet dealing with synthetic lactoflavine, which they now manufacture. This substance is phosphorylated after ingestion, and then forms the prosthetic group of Warburg's yellow ferment, which probably plays an essential part in oxidations in all body cells. It cannot be synthesized in the body, and forms one constituent of the complex of substances once known as vitamin $B$. 